\title{
Horizontal Versus Vertical Coopetition: The Tunisian Manufacturing Industry
}

\author{
Asma Zgarni ${ }^{1}$ \\ ${ }^{1}$ Management Assistant, El Manar University, FSEG, Tunis \\ Correspondence: Asma Zgarni. E-mail: asmazg12@yahoo.fr
}

Received: July 17, 2019

Accepted: August 1, 2019

Online Published: August 30, 2019

doi:10.5539/ass.v15n9p30

URL: https://doi.org/10.5539/ass.v15n9p30

\begin{abstract}
By opting for coopetition strategy, some companies prefer the horizontal one while others opt for the vertical. Furthermore, some coopetitions are rather aggressive, while others are rather cooperative. Nevertheless, the reasons for using one or the other of these strategies remain still ambiguous.

This article aims to explain the reasons, both internal and external, for the use of each type of coopetition and its nature. By adopting a quantitative hypothetico-deductive approach, and through a sample of Tunisian industrial companies, this study confirms that the need for strategic capabilities holds the strongest weight that the competitive intensity in the explanation of the coopetition type and its nature.
\end{abstract}

Keywords: competition intensity, strategic capabilities, horizontal coopetition, vertical coopetition, propensity for aggression, propensity for cooperation

\section{Introduction}

This research is part of the new approaches aimed at studying the explanatory factors of different strategies of coopetition (horizontal and vertical) and their nature (aggressive or cooperative).

In fact, the coopetition strategy is becoming the strategic standard and the only option for ensuring the survival and sustainable development of businesses in most sectors (Cygler et al., 2018). However, companies differ in their choice of coopetition. Some choose horizontal coopetition, while others opt for vertical coopetition. On the other hand some coopetitions are rather aggressive whereas others are rather cooperative. Nevertheless, the reasons for using one or the other of these strategies remain ambiguous.

In fact, the explanatory factors of coopetition have given rise, despite timidly, to a certain amount of empirical research (Dagnino et al., 2007; Fernandez \& Le Roy, 2010; Gnyawali \& Park, 2009; Sanou, 2012; Roy et al., 2013; Le Roy et al., 2014). Nevertheless, these researches have not yet resulted in a consensus on the reasons for using this new strategy. Indeed, the literature admits the existence of two main types of factors that may explain the use of coopetition strategies. External factors refer in particular to shorter product life cycles, industrial concentration, sectoral maturity, environmental uncertainty (Gnyawali \& Park, 2009; Sanou, 2012; Chiambaretto \& Fernandez, 2016; Cygler et al., 2018). However, internal factors revolve around the need for strategic resources (Bengtson \& Kock, 1999; Dagnino et al., 2007; Fernandez \& Le Roy, 2010).

In addition, comparative studies of the explanatory factors of the different strategies of coopetition (horizontal and vertical) and their nature (aggressive or cooperative) are still much more timid (Hillman et al., 2009; Gnyawali \& Park, 2011; Le Roy \& Sanou, 2014; Chiambaretto \& Fernandez, 2016).

The aim of this article is therefore to fill this gap and to study the comparative explanatory factors of vertical coopetition and horizontal coopetition and their natures (aggressive or cooperative) in the Tunisian manufacturing industry by focusing on the intensity' competition as the main external factor and the need for strategic capabilities as the main internal factor. The question then will be:

To what extent does the intensity of competition and the need for strategic capabilities lead to the choice of horizontal coopetition at the expense of vertical coopetition? And is this chosen coopetition rather aggressive or cooperative?

In an attempt to answer this question, certain hypotheses were emitted and tested on a sample of Tunisian industrial enterprises. Empirical results will no doubt useful to practitioners as well as public decision-makers. 
For this, this document has been structured as follows: a first section was devoted to the review of the literature dealing firstly with coopetition, in particular its theoretical field, its typology, and its advantages and disadvantages, and secondly on the determinants of coopetition, with particular reference to the approach to competitive forces and the resource approach. A second section is dedicated to the development of the research model and hypotheses. The third section was devoted to the presentation of the research methodology that has been adopted in this article. The fourth section of this document presents the results of the research. The next section focused on discussions of research findings. A later section was intended to deduce the managerial implications. Finally, the last section was devoted to the conclusions and limitations of the study.

\section{Theoretical Framework}

\subsection{The Strategic Choices of Coopetition}

Cooperation and competition have been widely regarded as the two opposite extremes of a broad continuum, because these two strategies are based on two entirely opposite paradigms (the theory of industrial organizations and socio-economic theory) or even incompatible (Fernandez et al., 2010). Nevertheless, the end of the 90s, experienced recognized attempts to bring these two opposing currents closer together by referring to the term "alliances between competitors" which corresponds to "associations between several competing or potentially competing firms" (Hamel et al., 1989; Contractor \& Lorange, 1988; Doz, 1996; Garrette \& Dussauge, 1995). However, the strong growth of recourse to this type of strategy that involves multiple adversaries and partners has given rise to a new terminology to describe this rather complex and paradoxical phenomenon, namely "coopetition". (Fernandez et al., 2010; Fernandez \& Le Roy, 2010) According to Fernandez et al. (2010), this new concept of "coopetition" adds to that of "alliances between competitors" a new dimension namely the simultaneity of these two dimensions, which have always been seen as antagonisms, was the basic foundation of this new concept. In the framework of the coopetition strategy, cooperation and competition are rather considered as interdependent opposites (Chen, 2008, cited by Fernandez \& Le Roy, 2010).

At this stage, it is not unimportant to recall that this increasing use of coopetition, which marked the end of the 1990s and which brings together simultaneously cooperative strategies and competitive strategies (Luo, 2004), finds explanations in the unusual intensification of competition, the products cycles of life becoming shorter, and increased research and development costs.

\subsection{Theoretical Fields, Definitions and Paradoxes of Coopetition}

Coopetition, as conceived by new research in this field, does not correspond to an extension of cooperation theories or competition theories. It is rather a new field of autonomous research (Battista Dagnino, quoted by Le Roy \& Yami, 2007). Researchers thus refer to certain theories to arrive at a precise and specific conceptualization of coopetition, in particular game theory (Nalebuff \& Brandenburger, 1996; Lado et al., 1997), resource-based theory, and the theory of social networks (Lado et al., 1997). Therefore, coopetition was first theorized from the notion of "value network" and was defined by Nalebuff and Brandenburger (1996) as the reconciliation of the "complementary" interest that manifests itself when competition and cooperation occur simultaneously (Le Roy \& Yami, 2007).

This definition clearly reveals the difference between coopetition, competition and cooperation, in the following three points:

- $\quad$ "The interdependence between companies is both a source of economic value creation and the place of sharing of this economic value;

- The interdependence between firms is based on a positive and variable sum game that must bring mutual benefits to partners, but not necessarily equitable ones;

- In a positive and variable sum game, the interdependence of firms is based on a function of inter-firm interests "(Dagnino et al., 2007, p. 95).

Subsequently, and over the years, the term coopetition has had several definitions. According to Bengtson and Kock (2000, p. 412) coopetition corresponds to a "dyadic and paradoxical relationship that emerges when two companies cooperate in some activities and at the same time compete with each other on other activities". For Chien and Peng (2005), it is defined as a cooperative and competitive strategy pursued by the company for the purpose of developing its market or limiting costs, strengthening its competitiveness and winning a leading position in the market.

Coopetition is also defined as the simultaneous adoption of two contradictory behaviors: aggressive behavior and / or cooperative behavior with competitors. To say that a firm is coopetitive is to say that it also knows a high 
level of competitive aggressiveness and cooperativity (Sanou, 2012). In the same vein, Luo (2007) sees coopetition as simultaneous collaboration and competition with the same adversary partners. On their part, Dagnino et al. (2007, p. 95) consider that coopetition is "a system of actors that interact on the basis of a partial congruence of interests and objectives".

Given these definitions, we can predict that a firm is coopetitive when it knows both a high level of competitive aggressiveness and a high level of cooperativity (Sanou, 2012). These two dimensions (strong aggressiveness and strong cooperation) coexist in coopetition and demonstrate its paradoxical nature. The first dimension of competitive aggressiveness assumes that the firm is aggressive when it initiates a large number of complex competitive actions and reactions within a limited time frame (Gnyawali, He, \& Madhava, 2006; Sanou \& Le Roy, 2012; Ferrier, 2001; Smith, Grimm, \& Gannon, 1992). The second dimension of coopetition is that of cooperativity, which is defined as "the propensity of the firm to initiate cooperative actions and to become involved in cooperative actions in its sector of activity" (Sanou, 2012).

\subsection{Typology of Coopetition}

The review of the literature allowed us to retain several typologies of coopetitions based on various criteria proposed by various authors. In this regard, we mention Dagnino and Padula (2002), who propose four forms of coopetition based on two axes, namely the number of companies involved in the cooperation and the number of activities in the value chain carried out in cooperation with competitors (cited by Le Roy \& Yami, 2007): complex dyadic coopetition, simple dyadic coopetition, simple network coopetition, complex network coopetition. As for Garraffo (2002), he distinguish four types of coopetition:

- Passive collaboration (mutual interaction required by law)

- Active collaboration (voluntary collaboration) in the form of agreements or coordinated actions

- $\quad$ Passive competition (indirect non-personal marketing)

- $\quad$ Active competition (includes sales activities)

Czakon and Rogalski (2014) propose another type of coopetition, namely lateral coopetition or of network. For his part, Luo $(2004,2005)$ presents a typology of coopetitive relations with multinationals based on the intensity of competitive and collaborative relationships. Lamberg, Ojala and Sajasalo (2007) propose a typology of coopetition based on the analysis of the value chain of the forest industry. By combining the typologies proposed by Lamberg, Ojala and Sajasalo (2007) and by Luo (2004), Gnywawali et al. (2008) offer a model derived from the combination of the model proposed by Dagnino and Padula (2002) with the distinction between horizontal and vertical coopetition. In the context of horizontal coopetition, cooperation takes place between the two competitors on some elements of the value chain that are upstream or downstream of the products for which they are in competition (Hamouti et al., 2014, Bengtsson et al., 2000; Le Roy et al., 2010). However, at the level of vertical coopetition, firms collaborate in partnership form in a client-supplier relationship, and are competing upstream or downstream of this cooperation (Pellegrin-Boucher \& Le Roy, 2009).

\subsection{Benefits and Risks of Coopetition}

Research on coopetition (Bengtsson \& Kock, 1999; Nalebuff Brandenburger, 1996) see themselves concordant that the pursuit of a coopetition strategy allows firms to benefit both from the competitive advantages manifested by stimulating the search for new productive, rent-generating combinations, as well as the benefits of cooperation, which consist in gaining access to scarce and complementary resources of competitors (Chetty et al., 2003; Zineldin, 2004; Pellegrin-Boucher \& Le Roy, 2009) particularly they are non-tangible and unavailable in order to reduce then the risque of imitation (Cygler et al., 2018). Coopetition stimulate also the innovation of partners and the development of technologies (Cygler et al., 2018).

However, these researches do not fail to discuss the risks of coopetition, which can be summed up in the high probability of imitation of one's own resources and competences by the adversary partner who can often be the main hidden motive of this coopetition (Prévot, 2007 quoted by Fernandez \& Le Roy, 2010). A loss of organizational independence and decision-making is also a dangerous threat stemming from coopetition (Cygler et al., 2018).

Moreover, coopetition can be a way to chase information or other intangible assets or even a trick for spying on the partner (Lavie, 2006). In addition, conflicts in coopetition can be a source of weakening of the cooperation efficiency and even of the objectives effectiveness pursued individually or commonly by coopetitors. They can also negatively affect the image of the company (Cygler et al., 2018). Besides, coopetition may incur operating costs that increase the financial situation of the company (Ritala et al., 1996). 


\section{The Determinants of the Strategic Choices of Coopetition}

Based on network theory and resource-based theory, Bengtson and Kock (1999) defined two factors that determine the choice of firms between a purely competitive, purely cooperative or coopetition strategy, namely: the need for surplus resources and the relative position on the sector. According to these two authors, it is according to the intensity of these two factors (strong or weak) that companies choose a particular type of behavior.

Table 1. Relationships between competitors

\begin{tabular}{lccc}
\hline & & \multicolumn{2}{c}{ Relative position on sector } \\
\cline { 3 - 4 } & & Strong & Low \\
\hline \multirow{2}{*}{ Need in resources excess } & Strong & Coopetition & Competition \\
& Low & Cooperation & Coexistence \\
\hline
\end{tabular}

Source: Dagnino et al., 2007

In the same vein, Fernandez and Le Roy (2010), while relying on the theory of resources, show that coopetition is not preferred as long as the internal resources of the company are sufficient and that the latter arrives at to achieve a competitive advantage on its own. However, it is because of the increased complexity of products and services that firms are often unable to own and develop the resources needed for their production alone. Indeed, companies' resources are heterogeneous, which makes them potentially complementary and interdependent. This is what drives them to look for the partner with the most complementary resources. Unfortunately, the most complementary potential partner can often be one of their main competitors. For Gnyawali and Park (2009), several factors are likely to favor the continuation of a coopetition strategy, namely: the short life cycles of products (characteristics of the industry); high research and development costs, technological convergence. On this point, Sanou (2012) has shown that the pursuit of a coopetition strategy is determined by sectoral variables such as industrial concentration, the sectoral maturity of the firm's domestic market; and its international presence. On the other hand, the adoption of such a strategy is also determined by the size of the firm. Referring to the resource dependency theory, Chiambaretto and Fernandez (2016) argue that environmental uncertainty can be a determining factor that fosters the development of coopetition strategies for the reason that with the intensification of competition, the need for similar resources can often only be found in a competitor.

As part of this work, we first refer to Porter's competitive forces approach in that it combines the main external factors proposed in the literature (industrial concentration, environmental uncertainty related to competitive intensity, etc.) that can guide companies' strategic choices, especially coopetition. In a second step, we try to explain the use of coopetition based on the resource approach (Bengtson \& Kock, 1999; Fernandez \& Le Roy, 2010).

\subsection{The Competitive Forces Approach}

The early work of the Harvard Business School (1965) on corporate strategy eventually established the LCAG model which postulates that a company must conduct a double external analysis (opportunities and threats of the environment) and internal (forces and weaknesses of the company) to develop its own strategy. Despite their merit, this work does not attribute a valuable role to the knowledge of competition. The latter did not know a first explicit and expanded development only with the work of Porter (1980) on competitive forces that come from the industrial economy (SCP) but are much richer. Indeed, according to Porter (1980, p. 3) "the structure of a sector has a strong influence on the determination of the competitive rules of the game and on the strategies to which the firm is able to resort". As a result, the competitive intensity relative to a business sector depends on the state of the five structural forces (existing competitors, potential entrants, substitute products, customers, suppliers).

This approach allows a complete and enriched analysis of the industry and its evolution, competitors and the positioning of the company in relation to its competitors, which allows the development of a competitive strategy aimed at supporting the position of the company on the market (Galbreath \& Galvin, 2008).

Nevertheless, despite its considerable contributions, this approach is criticized for its structuralist view of competition as it only uses the characteristics of the sector in the development of companies' strategic choices, while neglecting the actual interaction of competitors. Added to this is the interest brought in external factors at 
the expense of internal factors in the development of strategic choices. Indeed, the differences in performance recorded within the same industry have led some authors to question the real antecedents of strategic choices of companies (Rumelt, 1984). The resource approach brings, for the first time, the answer.

\subsection{The RBV Approach}

\subsubsection{Emergence and Basic Ideas}

This approach dates back to the work of Barnard (1938), Seznich (1957), and Chandler (1962), who emphasized the role of the firm's capabilities in using its resources for the creation of economic performance. However, it was Penrose (1959) who proposed a first new vision of the company while defining it as a collection of physical resources (factories, equipment, land, materials, etc.) and human resources (workers, management team, engineers, etc.) who are available to managers. While attributing to this "internal world" of resources a weight comparable to that of external forces (competitive pressure or customer requirements), this author presumes that it is the combination of these resources that generates the creation of unique subjective and specific productive opportunities that promote growth for each company.

Following this work, the Harvard School (1965), which has proposed a composite model (SWOT), has combined both external factors (opportunities and threats of the environment) and internal factors (strengths and weaknesses of the company) when developing strategic choices. These later internal factors incorporate implicitly the resources and skills of the company.

However, the first institutionalization of the resource approach goes back to the work of Wernerfelt (1984) who proposed the term Resource Based View (RBV) and which stipulated that the resources of the enterprise correspond to its strengths and weaknesses as established by the SWOT model. The author Barney (1991), meanwhile, has just linked the resources of the company to the sustainable and durable competitive advantage that can create, by considering that these resources correspond to "all assets, capacities, organizational processes, firm's attributes, information, knowledge, etc. controlled by a firm that allows it to design and implement strategies that improve its efficiency and effectiveness".

This approach has generated a certain revolution in the strategic thinking of the moment when the company sees itself as a collection of unique resources with a considerable impact not only on its evolution and its strategic development choices, but also on its competitive advantage and its annuities (Barney, 1991; Dierickx \& Cool, 1989). It breaks with traditional approaches where resources are considered mobile and homogeneous to attribute the cause of companies' heterogeneity to the fact that these resources are not perfectly mobile between firms (Barney, 1991). Added to this, is the fact that companies do not always have the same resource endowments (Foss, 1997).

In this regard, Barney (1996) points out that some resources, when present, favor a particular type of generic strategic choice. Thus, the presence of a significant experience effect favors the strategy of domination by the costs while the reputation favors the differentiation. Fernandez and Le Roy (2010), for their part, assume that the RBV theory is a stimulus to the pursuit of an individual strategy and this because the isolation of the company allows it to create sustainable unique resources. On the other hand, if companies have a strong need for resources (complementary or similar), they are obliged to cooperate vertically and sometimes even to ally with a competitor and coopeete (Koenig, 1996; Bengtsson \& Kock, 2000).

\subsubsection{Strategic Capabilities}

The pioneering work on resources uses the terms resources and capacities indistinctly to designate the same meaning. It will be necessary to wait for Amit and Schoemaker (1993) to propose a first considerable distinction between these two terms. According to these authors, the resources refer to the assets owned and controlled by the company whereas the capacities indicate the ability of the firm to exploit and combine these resources through the organizational routines aiming at accomplishing its path. These resources interact in a rather complex way, providing specific, tangible and intangible information processes that build capacities. The latter, when they are strategic, can have the effect of increasing the competitiveness of the company by promoting the creation of a sustainable competitive advantage, increasing production efficiency and improving deliveries (Day, 1994; Spanos \& Lioukas, 2001; Desarbo et al., 2005).

Researchers highlight various types of strategic capabilities, as each firm develops a specific configuration of capabilities that is rooted in the realities of its competitive market, past commitments, and projected needs (Grant, 1991). Still, it is important to note that there are certain types of capabilities that can exist in any business, especially those that correspond to key value creation processes, such as strategic managerial, technology, marketing, market-link and information technology capabilities. 
However, if it is true that the RBV approach brings a new understanding of the strategic process to the neoclassical approach, it continues to view competition as a struggle by referring to new barriers to entry (resources or capabilities). This suggests the complementarity of these two approaches in explaining profits and strategic choices.

\subsection{Complementarity of the Porterian Approach and the Resources' Approach}

Researchers unanimously agree that these two approaches have differences as well as similarities that justify their complementarity (Amit \& Shomaker, 1993; Barney \& Zajac, 1994). For example, Spanos and Lioukas (2001) argue that both of these approaches encourage higher-than-normal returns and therefore an attractive strategic position (Conner, 1991). Nevertheless, these authors argue that these two approaches differ on the nature of rent (monopolistic / Ricardian) and explanatory factors for strategic choices (external / internal).

To this end, researchers agree on their complementarity because value creation stems logically from the internal capacities of the strategy adopted and from the strategy to the competitive environment (Barney \& Griffin, 1992) and Barney (1992) cited by (Spanos \& Lioukas, 2001). On this same point, Barney and Zajac (1994) and Barney, Spender and Reve, (1994) assume that the examination of the skills needed to implement the strategy must necessarily join the analysis of the competitive environment of the firm and vice versa (Penrose, 1959; Amit \& Schoemaker, 1993). This complementarity has already been recognized by the SWOT model integrating resources (strengths and weakness of the company) and the competitive environment (opportunities and threats from the environment) (Foss, 1996)

This complementarity calls for the combination of these two approaches in the explanation of the strategic choices and this because they complement each other in the explanation of the source of the competitive advantage and the performance and that they highlight the same phenomena, namely: sustainable competitive advantage and strategic choices (Spanos \& Lioukas, 2001).

\section{Development of the Model and Hypotheses}

This work refers to a dual theoretical framework grouping the porterian approach and the RBV presented above and proposes a composite model explaining the choice of coopetition strategies (Figure 1). This conceptual model that we propose stipulates that the intensity of competition, orients differently the different strategic choices of coopetition (horizontal and vertical) and their nature (aggressive or cooperative), and that these strategic choices and their nature also depend on the possible company's provision of sufficient strategic capabilities.

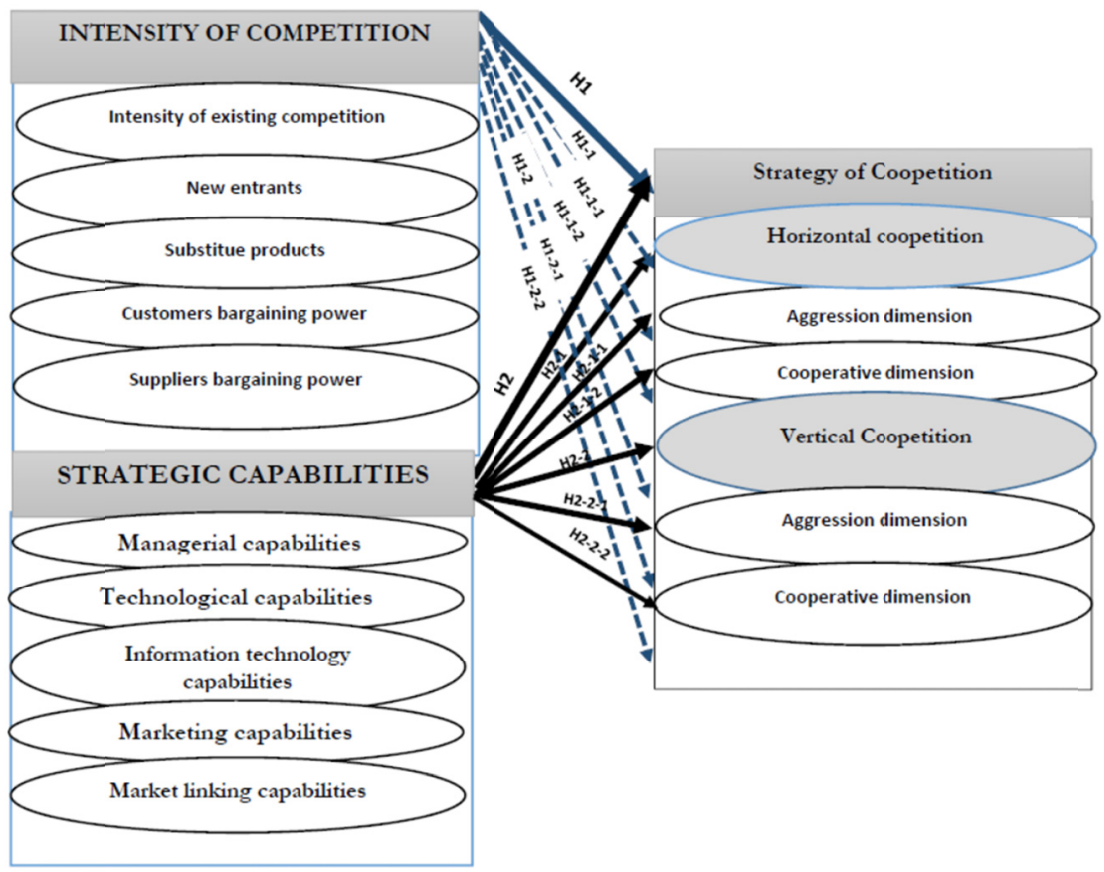

Figure 1. Conceptuel model

The objective is to determine the factors (competition 'intensity and strategic capabilities) that favor the use of 
horizontal coopetition to the detriment of vertical coopetition and rather aggressive coopetition to the detriment of cooperative coopetition.

\subsection{The Impact of the Competition Intensity on Coopetition Strategies}

The assumptions of the competitive forces approach have been relatively tested not only in the field of competitive strategies but also in the field of cooperation and coopetition strategies. However, the review of the literature allows us to remember that the research conducted on this topic is still shy about the nature of coopetition (horizontal or vertical) favored in the context of a highly competitive environment. As such, we cite Shan's work (1990), which proved that the high intensity of competition favors the formation of alliances. Very recently, the empirical study of Chiambaretto and Fernandez (2016) shows that the high environmental uncertainty encourages companies to move much more towards coopetition strategies than towards pure cooperation strategies. By evocating two types of coopetition (horizontal and vertical), Hamouti et al. (2014) have just confirmed that to succeed in innovating in a highly competitive environment, companies must make greater use of both vertical and horizontal coopetition.

As for the aggressive or cooperative nature of the coopetition conducted, the researches are much more lacking. In this framework of ideas, Luo (2007) argues that the intensity of competition pushes to develop the competitive dimension of coopetition as well as the cooperative dimension. Indeed, in terms of the cooperative dimension, the response of coopetitors to competitive threats is to intensify collaboration to strengthen their bargaining power and to impose new barriers to entry (through predatory pricing, manipulation of technological standards, pressuring governments to use more stringent policies). These claims are justified by the example of Simens who strengthened his collaboration with his rival Motorola when he realized that the competitive threats of competitors like Hitachi, 3Com, Cisco, Acer and Samsung have increased. Simens and Motorola have jointly strengthened the technology standards and put pressure on the Chinese government not to ratify project developers in cities where they had already invested and operated.

With regard to the competitive aggressiveness dimension, Luo (2007) argues that the propensity for competitive aggression tends to increase with the intensification of competition, especially in the context of a mature industry where coopetitors tend to compete fully with each other in order to maximize the rent of their respective positions in the market. To assert this, the author illustrates the example of Sun Microsystems where competition between semi-conductor producers, including Toshiba, Unisys, Fujitsu, Philips and Matsushita, has increased dramatically when RISC technology has become obsolete after IBM (Whose PC unit was acquired by Lenovo in China 2005 for $\$ 1.75$ billion), Motorola and Apple jointly developed the PowerPC chip and Intel has redoubled its efforts to develop the Pentium chip. Similarly, when firms are targeting the same market, the same competitive strategy, the same element of competitive advantage or the similarity of products is growing, the propensity for competitive aggression is increasing. These claims are justified by the example of Germany Bertelsmann and France Vivendi Universal, two of the world's largest media groups that cooperate and compete, have increased their rivalry by striving to compete in each other's domestic markets (Largest market community) Vivendi finally turned to the marketing of sports teams and events in Europe, a zone long dominated by Bertelsmann (Increasing the similarity of the portfolio).

Following the above developments, we make the following central hypothesis:

Hypothesis 1: The competition' intensity favors coopetition strategies

From this hypothesis follow the following sub-hypotheses:

Hypothesis 1-1- the competition' intensity favors horizontal coopetition strategies

Hypothesis 1-1-1: The competition 'intensity favors the propensity for cooperation of horizontal coopetition

Hypothesis 1-1-2: The competition 'intensity favors the propensity for aggression of horizontal coopetition

Hypothesis 1-2- the competition' intensity favors vertical coopetition strategies

Hypothesis 1-2-1: The competition 'intensity favors the propensity for cooperation of vertical coopetition

Hypothesis 1-2-2: The competition 'intensity favors the propensity for aggression of vertical coopetition

\subsection{The Impact of Strategic Capabilities on Coopetition Strategies}

Since the founding works on coopetition (Bengtsson \& Kock, 1999), the high need for excess resources seems to be one of the determining factors in pursuing a strategy of coopetition. However, these researches have not made a clear distinction between the primacy of horizontal coopetition over vertical coopetition, or the opposite depending on the level of resource requirement. Le Roy and Fernandez (2010), in an empirical study of the 
European space industry, simply, show that companies are increasingly opting for coopetition when they lack internal resources to create a competitive advantage in isolation. In parallel, Miotti and Sachwald (2003) find in their empirical study that the strategic need for effort in research and development increases the tendency of companies to cooperate with a competitor. This cooperation with rivals aims to pool similar resources in order to cope with high R \& D costs.

As for the aggressive or cooperative nature of coopetition, researches are also timid. Luo (2007) shows that the propensity for competitive aggression tends to increase when the interdependence of resources among coopetitors tends to decrease. However, when it is strong, it has the effect of favoring the intensity of the propensity to cooperate (Henderson \& Mitchell, 1997). These claims are justified in the case of the German company Vodafone and the French company Vivendi Universal, which have long coopeete (compete and cooperate). However, with the dissolution of Vizzavi, (their joint venture on the Internet), their mutual competition has increased significantly in European mobile markets due to their low interdependence in resources.

Based on the above reflections, we can formulate the following hypotheses:

Hypothesis 2: Insufficient strategic capabilities favors the adoption of coopetition strategies

From this hypothesis, several sub-hypotheses can emerge:

Hypothesis 2-1: Insufficient strategic capabilities favors the adoption of horizontal coopetition strategies

Hypothesis 2-1-1- Insufficient strategic capabilities favors the propensity for cooperation of horizontal coopetition

Hypothesis 2-1-2- Insufficient strategic capabilities favors the propensity for aggression of horizontal coopetition Hypothesis 2-2: Insufficient strategic capabilities favors the adoption of vertical coopetition strategies

Hypothesis 2-2-1- Insufficient strategic capabilities favors the propensity for cooperation of vertical coopetition Hypothesis 2-2-2- Insufficient strategic capabilities favors the propensity for aggression of vertical coopetition

By comparing the effect of the two factors studied on the continuation of coopetition strategies, we propose the following hypotheses:

Hypothesis 3: Insufficient strategic capabilities has a more decisive effect than competitive intensity in adopting coopetition strategies

Hypothesis 3-1: Insufficient strategic capabilities has a more decisive effect than competitive intensity in adopting horizontal coopetition strategies

Hypothesis 3-2: Insufficient strategic capabilities has a more decisive effect than competitive intensity in adopting vertical coopetition strategies

\section{Research Methodology}

\subsection{Measurement of Variables}

With the exception of the "intensity of existing competition" dimension, which was measured by the scale proposed by Mia and Clarke (1999) in an adapted version of the Khandwalla scale (1972) but used in a Al-Rfou's own version (2012), the four other competitive forces (threat of new entrants, threat of substitute products, bargaining power of customers, bargaining power of suppliers) were measured by the scales of measurement proposed by Weerawardena (2006) based on the scales developed by Pecotich et al. (1999).

To measure the constructs of different strategic capabilities (managerial, technological, information technology, marketing and market linkage), this research refers to the scales proposed by Desarboo et al. (2005).

Regarding coopetition, Fernandez et al. (2010), argue that researchers in management sciences must incorporate multidimensionality as an additional constraint when it comes to measuring this phenomenon of coopetition. Nevertheless, although the measures used to date, incorporate the two dimensions of coopetition (competition and cooperation), they offer only an indirect measure (Fernandez et al., 2010) which revolves around the measurement of cooperation in the competition (network framework) or vice versa (Gnyawali, He, \& Madhavan, 2006, Andrevski, Ferrier, \& Bras, 2007). In order to fill this gap and take into account the bi-dimensionality of the coopetition variable, and while trying to make a direct measure of coopetition, we have tried to measure coopetition through a competitive dimension and a cooperation dimension. Thus, we measured the "propensity for cooperation" dimension through the scale proposed by Luo et al. (2007). As for the second dimension relating to competitive aggression, we used the Le Roy' scale (1996, 2001). This scale was similarly adapted to 
the needs of our study by using it once for vertical coopetition and a second time for horizontal coopetition.

For all the items on the chosen scales of measurement, respondents are asked to rate, on a seven-point Likert scale ranging from 1 "very low" to 7 "very high" their attitudes towards the different variables of the 'study.

\subsection{Sampling, Administration and Data Collection}

As part of this work, we opted for the reasoned choice sampling method, since it was judged that the sample with the characteristics listed below can enable us to achieve the objectives of the research. Indeed, the mother population assembles companies of the Tunisian manufacturing industry (the sector of textile and clothing, the sector electrical, electronics and household appliances, the chemical sector and, the sector agro-alimentary) of small, medium or large sizes, all regime of activity combined (totally exporting and other than totally exporting). With regard to the questionnaire, the validity of content (consensus validity and facial validity) was verified first through its submission to the appreciation of peers and experts, who made us benefit from certain recommendations concerning certain items. Subsequently, this questionnaire was tested through a pre-test with 12 companies, which allowed us to clarify and rephrase some misunderstood or inadequate questions. Then, we administered it, in its final version, to the general managers (CEOs) of the companies in our sample while opting for the face-to-face mode which has the advantage of favoring a high control of the sample and a more reliable information. Of the 400 questionnaires distributed, only 236 copies were returned with a return rate of $59 \%$ of which only 203 were exploitable and fully populated (no missing data) with an $85.5 \%$ actionable response rate.

\section{Results}

The results of the empirical study (Table 3) carried out cannot be used before making sure of the reliability and the dimensionality of the different scales of measurement used by means of a first purification through the ACP and the calculation of the Alpha of Cronbach, then a second purification through the AFC. Having verified all these conditions of scientific rigor, the data were analyzed through the method of structural equations which showed a good quality of fit of the global model. At this stage, we were able to empirically validate the research hypotheses and announce the results obtained.

Thus, the empirical study carried out shows that the intensity of competition has a positive and significant effect on both horizontal and vertical coopetition strategies. This allows us to confirm our hypotheses H1, H1-1 and H1-2.

As for the second explanatory variable of our model, the results of the empirical investigation initiated show the existence of a negative and significant effect of the strategic capabilities on the different strategies of vertical and horizontal coopetition, which exiles us to confirm Hypothesis H2, H2-1 and H2-2.

Regarding the effect of competitive intensity on the propensity for aggression and cooperation, we found that in the case of horizontal coopetition, the propensity for competitive aggression increases while the propensity for cooperation decreases with the competition 'intensity. This allows us to confirm H1-1-1 but to overturn H1-1-2. However, in the context of vertical coopetition, the intensity of competition seems to have a negative effect on both the cooperative and the aggressive dimension, thus allowing us to confirm H1-2-1 and H1-2- 2 .

Concerning the effect of strategic capabilities on the propensity for competitive aggression as well as cooperativity, it turns out to be negative and significant for both horizontal and vertical coopetition, thus confirming the hypotheses $\mathrm{H}$ 2-1-1, H2 -1-2, H2-2-1 and H2-2-2.

The comparison of the coefficients in absolute value of the two factors allows us to confirm that the "strategic capabilities" factor holds the strongest weight that the competitive intensity in the explanation of the two types of coopetition and this despite its negative sign in both cases. Thus allowing us to confirm H3-1, H3-2 and consequently $\mathrm{H} 3$.

\section{Discussions}

This empirical investigation has taught us that the intensity of competition determines the strategies of coopetition. More specifically, competitive intensity seems to have a negative impact on vertical coopetition strategies while having a positive impact on horizontal coopetition strategies. Given that horizontal coopetition strategies are mainly developed in R \& D activities, the development of new products, the improvement of the existing technology within our sample, we can therefore affirm like Hamouti et al. (2014) on a sample of the video game industry that compared to the competitive intensity, it is the horizontal coopetition which is privileged compared to the vertical coopetition and which proves the major source of the radical innovation. This type of coopetition provides access to the partner resources most needed to compete in the market (Hamouti et al., 2014). Indeed, a context marked by a strong competitive intensity is likely to require radical innovation that 
requires resources that are found only in the strongest competitor (Chiambaretto \& Fernandez, 2016). As for the vertical coopetition strategy, it is mainly focused on the development of new products, improvement of existing technology, sales and market segmentation and does not allow access to the resources needed for production, which explains the low use of this strategy when competition intensifies. In fact, when the intensity of competition is moderate, the need to innovate becomes more modest (incremental innovation), hence the use of vertical coopetitions, where cooperation is carried out on the products of suppliers (which are at the same time competitors) or on the activities or distribution channels of customers (who are concurrently competitors) but do not allow an innovation of the company's products (Hamouti et al., 2014). These results are in line with those of the empirical study of Eisenhardt and Schoonhoven (1996), who, by testing the relationship between the competition 'intensity and the use of alliance strategies with a competitor, find that firms make recourse increasingly to alliance strategies when the number of competitors is high in an industry. Along the same lines, we also join Shan (1990) who proves, on a sample of entrepreneurial biotechnology firms, that the high intensity of competition favors the formation of alliances.

To further these investigations and digging deeper into the analysis of coopetition, focusing on the cooperative and aggressive intensity of this strategy, the results show that in the case of horizontal coopetition, the propensity for aggression while the propensity for cooperation decreases with the intensification of competition. This coopetition situation can be described as conflictual, as Luo (2007) suggests. These results are in part consistent with Luo's (2007) claims who stipulate that the competition 'intensity has the effect of reinforcing the competitive dimension of coopetition. However, our results conflict with Luo (2007) regarding the cooperative dimension of horizontal coopetition. Similarly, for vertical coopetition, the intensity of competition seems to have a negative effect on both the cooperative dimension and the aggressive one, annoying thereby Luo (2007). This coopetition situation is described as a situation of isolation according to the terms of Luo (2007).

As for the competitive aggression dimension, the results of this paper are in line with Luo's (2007) comments for horizontal coopetition, but thwart them for vertical coopetition. One possible explanation is that the sectors subject to horizontal coopetition are in the maturing phase, which leads to more competitive aggression (Baum \& Korn, 1999) or that coopetitors adopt the same competitive strategy, target the same market, or have a strong similarity of products (Luo, 2007). However, as far as the cooperative dimension is concerned, our results contradict Luo (2007) in terms of both horizontal coopetition and vertical coopetition. Indeed, Luo (2007) argues that the cooperative dimension of coopetition increases with competitive intensity. According to this author, coopetitors' response to competitive threats is to intensify collaboration in order to strengthen their bargaining power, impose new barriers to entry (through predatory pricing, manipulation of technological standards, put pressure on governments to they use harsher policies).

In terms of the effect of the firm's strategic capabilities on coopetition strategies, it manifests itself in a variety of relationships. Indeed, our empirical investigation has allowed us to agree that the lack of strategic capabilities favors the vertical and horizontal coopetition strategy. Nevertheless, it is important to note that in our sample, companies have an interest in opting for vertical coopetition slightly more than horizontal coopetition when their resource requirements are higher. This result cannot be explained independently of the factor "competitive intensity". To this end, we assume that the competitive environment of these companies is not so intense, which implies that the resources required for innovation and performance are only upstream or downstream of the production process and that the chosen vertical coopetitors are rich in these resources, which prove to be sufficient in this context. Thus, a cooperation on the products of the coopetitor suppliers or on the distribution and communication channels of the coopetitor customers proves to be sufficient in view of the need for resources felt and has the advantage of better protecting the key resources of the coopetitors.

This result diverges from that of Hamouti et al. (2014), which prove that companies prefer the adoption of horizontal coopetition because it is the most efficient for coopetitors since it makes it possible to boost the sales of the two coopetitors and to increase their respective market shares. However, in the context of vertical coopetition, the customer or the supplier (who is at the same time a competitor) often engages in exclusive contracts with the cooperator which limits his potential gains.

In order to further refine our investigations, we considered it useful to deepen the analysis of coopetition taking into account its two-dimensional nature. Our empirical results allow us to conclude that the insufficiency of the strategic capacities favors the propensity for cooperation and the competitive aggressiveness towards the coopetitors in the two cases of coopetition (horizontal and vertical). Therefore, we find that the lack of resources is a factor favoring the horizontal and vertical coopetition of "adaptation" type as proposed by Luo (2007), where the aggressive and cooperative dimension are the strongest possible. This is partly consistent with the statements of Bengtsson and Kock $(1999,2000)$ and Luo (2007) who argue that the propensity for cooperation increases 
with the increased need for resources. However, we oppose Luo's (2007) comments on the propensity for aggression. Indeed, this author argues that the propensity for competitive aggression tends to increase when the interdependence of resources among coopetitors tends to decrease. However, when this interdependence is strong, it has the effect of favoring the intensity of the propensity to cooperate (Henderson \& Mitchell, 1997). As such, this author proves that because of the low interdependence in resources of the company Vodafone and the company Vivendi Universal, which have long cooperated, their mutual competition has significantly increased in the pan-European mobile markets by the collapse of their joint venture.

The comparison of the absolute value coefficients of the two types of factors allows us to affirm that the "strategic capabilities" factor holds a strongest weight than that the competitive intensity in the explanation of the two types of coopetition and this despite its negative sign in both cases. However, vertical coopetition depends more heavily on both strategic capabilities and competitive intensity than the horizontal coopetition.

The primacy of the "capability" factor in explaining coopetition strategies is thus fully in line with the assumptions of the resource approach which predicts that it is the lack of strategic resources that drives companies to opt for coopetition since the resources sought are most often found among the competitor (Chiambaretto \& Fernandez, 2016).

As for the different dimensions of the two types of coopetition, this study shows the primacy of the "capability" factor in the explanation of the aggressive and cooperative intensity for both horizontal and vertical coopetition. Indeed, the different coefficients relating to capabilities are higher in absolute value than those of the competitive intensity.

Finally, an attempt to compare the conditions of recourse to horizontal coopetition in the detriment of vertical coopetition or vice versa, and subject to simultaneous consideration of the two factors proposed in this research (intensity of competition and strategic capabilities), allows classification of recourse to these two strategies as shown in the matrix below (Table 2). The latter may constitute a very useful guide for Tunisian managers who can illuminate their path in terms of coopetition strategies.

Table 2. Matrix of strategic coopetition choices

\begin{tabular}{ccc}
\hline Competition intensity & Low & High \\
Strategic Capabilities & Vertical coopetition (isolement) & Horizontal coopetition \\
Low & Vertical coopetition (adaptation) & (conflictual) \\
& Horizontal coopetition(adaptation) & . \\
\hline
\end{tabular}

\section{Managerial Implications}

This research leads to attractive results that can be diagnostic and assessment tools for managers who can guide them in their strategic choices of coopetition in various situations of competitive intensity and strategic capabilities.

The study also highlights the crucial role that the lack of strategic capabilities can play in the orientation towards coopetition strategies. An important implication of this relationship is that coopetition strategies seem to offer a successful alternative for indigent businesses of these abilities. The latter are recommended to resort first to the vertical coopetition strategy and then to the horizontal coopetition strategy.

These results also send a message to companies in the industry, whose strategic choices depend on the strategic capabilities of their competitors, and who must distinguish between the real threats of competing firms versus companies that pass fictitious threats without being able to compete or have the resources to overcome the threat competition. Similarly, one must be cautious about certain companies that do not suffer from a lack of resources and that can propose to coopeete with the sole intention of accessing the competitor's key competencies. By the same token, public decision-makers can learn from this research, which, by ensuring that competition in Tunisian manufacturing industries and consumer welfare are well managed, must control the excessive use of coopetition strategies intended to eliminate competitors and monopolize the market.

\section{Conclusions}

This research is part of business strategies new approaches, including explanatory factors for the coopetition 
strategy. This study allowed us to draw a number of conclusions. First, the present study contributes to the enrichment of the debate on the determining factors of the different coopetition strategies, which has long focused on one of these two types of factors without bringing them together. Our study has the merit of showing that these two factors have simultaneously a considerable weight in the determination of the strategic choices of coopetition. Two strategic coopetition situations (horizontal and vertical) have been identified.

Secondly, this study has shown that coopetition is a two-dimensional phenomenon that cannot be reduced to a single reductive dimension (Fernandez et al., 2010). Indeed, we took the initiative to develop a two-dimensional and direct measure of dyadic coopetition across a scale that consists of two dimensions; a "cooperation" dimension and a "competitive aggressiveness" dimension, reflecting more deeply the reality and the specificity of this strategy.

However like all research work, ours does not lack limits. A first limit refers to the choice of the Tunisian manufacturing industry to test our conceptual model which remains strongly linked to the specificities of research (intense competition) and which is far from allowing us to generalize our results to other sectors or to other developing countries. This calls for a future inter-industry comparative analysis or with other developing countries that can decide on the possibility of extending or circumscribing the scope of our results.

In addition, the present problem can be taken up by integrating other explanatory factors of strategic choices of coopetition, such as a wider range of resources and strategic capabilities, the life cycle of products, the size of the firm, etc. (Roy et al., 2010; Gynawali \& Parck, 2009).

Finally, another limitation refers to the static nature of the competitive forces approach adopted. Indeed, behavioral factors, such as the characteristics of the company's actions and the competitors 'reactions, can be of a considerable explanatory contribution to the strategic choices of coopetition (Bensebaa, 2003; Le Roy, 2004). Future research could incorporate such factors.

\section{References}

Nahar, Al-R. A. (2012). Competition and Organizational Performance: Empirical Evidence from Jordanian Firms. Business Management, Tafilah Technical University, Tafilah 66110, Jordan. J Economics, 3(1), 13-17. https://doi.org/10.1080/09765239.2012.11884947

Amit, R., \& Schoemaker, P. J. (1993). Strategic assets and organizational rent. Strategic Management Journal, 14, 33-46. https://doi.org/10.1002/smj.4250140105

Andrevski, G., Ferrier, W. J., \& Bras, D. (2007). Social Capital and competitive behaviour: A study of interfirm networks and rivalry among auto makers. Academy of Management proceedings. https://doi.org/10.5465/AMBPP.2007.26530452

Barnard, C. (1938). The function of executives. Cambridge, Harvard University Press. https://doi.org/10.5465/amle.2017.0420

Barney J. B., \& Zajac, E. (1994). Competitive organizational behavior: toward an organizationally-based theory of competitive advantage. Strategic Management Journal, 15, 5-9. Winter Special Issue. https://doi.org/10.1002/smj.4250150902

Barney, J. B., Spender, J. C., \& Reve, T. (1994). Does Management Matter?: On Competencies and Competitive Advantage. Lund University Press. de Crafoord lectures, 6, 89.

Barney, J. B. (1996). The resource-based theory of the firm. Organization Science, 7(5), 469-469. https://doi.org/10.1287/orsc.75.469

Barney. J. B. (1991). Firm Resources and Sustained Competitive Advantage. Journal of Management, 17(1), 99-120. https://doi.org/10.1177/014920639101700108

Bengtsson, M., \& Kock, S. (2000). Coopetition in Business Networks-To Cooperate and Compete $\begin{array}{llll}\text { Simultaneously. Industrial Marketing } & \text { Magement, } & \text { 29, }\end{array}$ https://doi.org/10.1016/S0019-8501(99)00067-X

Bengtsson, M., \& Kock, S. (1999). Cooperation and Competition in Relationships between Competitors in Business Networks. Journal of Business \& Industrial Marketing, 14(3), 178-193. https://doi.org/10.1108/08858629910272184

Bensebaa, F. (2003). la dynamique concurrentielle et ses déterminants: défis analytiques et méthodologiques. $\begin{array}{lccc}\text { Finance-Contrôle-Stratégie, } & 6(1) . & \text { Retrieved } & \text { from }\end{array}$ http://crego.u-bourgogne.fr/images/stories/rev/061037.pdf 
Brandenburger, A. M., \& Nalebuff, B. J. (1996). Co-Opetition: A revolution mindset that combines competition and cooperation: the game theory strategy that's changing the game of business. Currency Doubleday, New York.

Chandler, A. D. (1962). Strategy and Structure: Chapters in the history of industrial enterprise. Industrial management-United states, corporations. Cambridge: M.I.T. Press. Retrieved from http://uf.catalog.fcla.edu/uf.jsp?

Chiambaretto, P., \& Fernandez, A. (2016). The evolution of coopetitive and collaborative alliances in an alliance portfolio: The Air France case. Industrial Marketing Management, 57, 75-85 https://doi.org/10.1016/j.indmarman.2016.05.005

Chien, T.-H., \& Peng, T.-J. (2005). Competition and Cooperation Intensity in a Network: A Case of Study in Taiwan Simulator Industry. Journal of American Academy of Business, 7(2), 150-156.

Conner, K. R. (1991). A historical comparison of resource-based theory and five schools of thought within industrial organization economics: Do we have a new theory of the firm? Journal of Management, 17(1), 121-154. https://doi.org/10.1177/014920639101700109

Contractor, F. J., \& Lorange, P. (1988). Why should firms cooperate? The strategy and economic basis for cooperative ventures. In F. J. Contractor, \& P. Lorange (Eds.), Cooperative Strategies in International Business (pp. 3-30). Lexington Books, Lexington, MA.

Cygler, J., Sroka, W., Solesvik, M., \& Debkowska, K. (2018). Benefits and Drawbacks of Coopetition: The Roles of Scope and Durability in Coopetitive Relationships. Sustainability, 10, 2688. https://doi.org/10.3390/su10082688

Czakon, W., \& Rogalski, M. (2014). Coopetition revisited-a behavioural approach. International Journal of Business Environment, 6(1), 28-46. https://doi.org/10.1504/IJBE.2014.058022

Dagnino, G. B., \& Padula, G. (2002). Coopetition Strategy: A new kind of interfirm dynamics for value creation. In II Annual Conference of EURAM. Stockholm: May 9-11. https://doi.org/10.1.1.194.5380\&rep=rep1\&type=pdf

Dagnino, Giovanni, B., Le Roy, F., \& Yamin, S. (2007). La Dynamique des stratégies de Coopétition. Revue Française de Gestion, 33(176), 87-98. https://doi.org/10.3166/rfg.176.87-98

Day, G. S. (1994). The Capabilities of Market-Driven Organizations Reviewed work(s). Journal of Marketing, 58(4), 37-52. https://doi.org/10.1177/002224299405800404

Desarbo, W. S., Di Benedetto, C. A., Song, M., \& Sinha, I. (2005). Revisiting the Miles and Snow strategic framework: uncovering interrelationships between strategic types, capabilities, environmental uncertainty, and firm performance. Strategic Management Journal, 26, 47-74. https://doi.org/10.1002/smj.431

Dierickx, I., \& Cool, K. (1989). Asset stock accumulation and sustainability of competitive advantage. Management Science, 35(12), 1504-1511. https://doi.org/10.1287/mnsc.35.12.1504

Doz, Y. (1996). Managing core competency for corporate renewal: Towards a managerial theory of core competencies. Organization and Strategy in the Evolution of the Enterprise, 155-178.

Eisenhardt, K. M., \& Schoonhoven, C. B. (1996). Resources-based View of Strategic alliance formation: strategic and social effects in entrepreneurial firms. Organization Science, $7(2)$. https://doi.org/10.1287/orsc.7.2.136

Fernandez, A.-S., \& Le Roy, F. (2010). Pourquoi Coopérer avec un Concurrent? Une approche par la RBV. Lavoisier. Revue française de gestion, 5(204), 155-169. https://doi.org/10.3166/RFG.204.155-169

Fernandez, A.-S., Marques, P., Le Roy, F., \& Robert, F. (2010). Mesurer la coopétition: Mission impossible? Revue Sciences de Gestion, 73.

Ferrier, W. J. (2001). Navigating the Competitive Landscape: The Drivers and Consequences of Competitive Aggressiveness. Academy of Management Journal, 44(4), 858-877. https://doi.org/10.5465/3069419

Foss, N. (1996). Research in Strategy, Economics, and Michael Porter. Journal of Management Studies, 33, 1-24. https://doi.org/10.1111/j.1467-6486.1996.tb00796.x

Foss, N. (1997). Resources and strategy: problems, open issues, and ways ahead. In N. Foss (Ed.), Resources, Firms and Strategies (pp. 345-365). Oxford University Press: New York.

Galbreath, J., \& Galvin, P. (2008). Firm factors, industry structure and performance variation: New empirical 
evidence to a classic debate. Journal of Business Research, 61, 109-117. https://doi.org/10.1016/j.jbusres.2007.06.009

Garraffo, F. (2002). Types of coopetition to manage emerging technologies. In 2nd annual conference, Innovative Research in Management, Stockholm, Sweden.

Garrette, B., \& Dussauge, P. (1995). Les Stratégies d'Alliance. Editions d'Organisation, Paris.

Gnyawali, D. R., \& Park, B.-J. R. (2009). Co-opetition and Technological Innovation in Small and Medium-Sized Enterprises: A Multilevel Conceptual Model. Journal of Small Business Management, 47(3), 308-330. https://doi.org/10.1111/j.1540-627X.2009.00273.x

Gnyawali, D. R., He, J., \&Madhavan, R. (2006). Impact of Co-opetition on Firm Competitive Behavior: An Empirical Examination. Journal of Management, 32(4), 507-530. https://doi.org/10.1177/0149206305284550

Gnyawali, D. R., \& Park, B. J. (2011). Coopetition between giants: Collaboration with competitors for technological innovation. Research Policy, 40(5), 650-663. https://doi.org/10.1016/j.respol.2011.01.009

Gnyawali, D. R., He, J., \& Madhavan, R. (2008). Co-opetition. Promises and challenges. In C. Wankel (Ed.), 21st Century Management: A Reference Handbook (pp. 386-398). London: Sage Publications.

Grant, R. M. (1991). The Resource-Based Theory of Competitive Advantage Implications for Strategy Formulation. California Management Review, 114-135. https://doi.org/10.2307/41166664

Hamel, G., Doz, Y., \& Prahalad, C. K. (1989). Collaborate with your competitor and Win. Harvard Business Review, (67), January-February, 133-139.

Hamouti, R., Robert, F., \& Le Roy, F. (2014). Stratégie individuelle, stratégie de coopération verticale ou stratégie de coopétition. Quelle est la meilleure stratégie pour l'innovation produit? Innovations, 1(43), 135-161. https://doi.org/10.3917/inno.043.0135

Henderson, R., \& Mitchell, W. (1997). The Interactions of Organizational and Competitive Influences on Strategy and Performance. Strategic Management Journal, 18(Summer Special Issue), 5-14. https://doi.org/10.1002/(SICI)1097-0266(199707)18:1+<5::AID-SMJ930>3.0.CO;2-I

Hillman, A. J., Withers, M. C., \& Collins, R., \& Brian, J. (2009). Resource Dependence Theory. A Review Journal of Management, 35, 1404. https://doi.org/10.1177/0149206309343469

Khandwalla, P. N. (1972). The Effect of Different Types of Competition on the Use of Management Controls. Journal of Accounting Research, 10(2), 275-285. https://doi.org/10.2307/2490009

Koenig, G., (1996). Management stratégique: paradoxes, interactions et apprentissages: construction et gestion des activités. Management d'exigences contradictoires. Paris, Nathan. Retrieved from http://hdl.handle.net/123456789/101919

Lado, A. A., Boyd, N. G., Hanlon, \& Susan, G. (1997). Competition, Cooperation and the Search for Economic Rents: A Syncretic Model. Academy of Management Review, 22(1), 110-141. https://doi.org/10.5465/amr.1997.9707180261

Lamberg, J.-A., Ojala, N. J., \& Sajasalo, P. (2007). The evolution of competitive strategies in global forest industries. Dordrecht: Springer.

Lavie, D. (2006). The competitive advantage of interconnected firms: An extension of the resource-based view. Academy of Management Review, 31, 638-658. https://doi.org/10.5465/amr.2006.21318922

Le Roy, F., Robert, M., \& Lasch, F. (2013). Coopérer avec ses amis ou ses ennemis quelle stratégie pour l'innovation produit? Revue Française de Gestion, 3(232), 81-100.

Le Roy, F. (1996). L'agressivité concurrentielle comme objet de recherché. Treizièmes Journées Nationales des IAE, 2, 395-408. IAE Toulouse, Toulouse.

Le Roy, F. (2001). Agressivité concurrentielle, taille d'entreprise et performance. Revue Internationale des PME, 14(2).

Le Roy, F. (2004). La concurrence: entre affrontement et connivence. Revue française de gestion, (148).

Le Roy, F., Robert, M., \& Lasch, F. (2012). Coopérer avec ses amis ou avec ses ennemis: Quelle stratégie pour la performance d'innovation produit en PME? lléme Congrès CIFEPME.

Le Roy, F., \& Yami, S. (2007). Les stratégies de coopétition. Revue Française de Gestion, 33(176). 
Le Roy, F., Yami, S., \& Dagnino, G. (2010). La coopétition: Une stratégie pour le vingt-et-unième siècle. In S. Yami, \& F. Le Roy (Eds.), Les stratégies de coopétition: Rivaliser et coopérer simultanément (pp. 17-28). DeBoeck, Collection Méthodes et Recherches, Bruxelles.

Le Roy, F., \& Sanou, F. H. (2014). Does coopetition strategy improve market performance? An empirical study in mobile phone industry. Journal of Economics \& Management, 17, 63. https://EconPapers.repec.org/RePEc:hal:journl:hal-02050858

Luo, X., Rindfleisch, A., \& Tse, D. K. (2007). Working with Rivals: The Impact of Competitor Alliances on Financial Performance. Journal of Marketing Research, 44(1), 73-83. https://doi.org/10.1509/jmkr.44.1.073

Luo, Y. (2007). A coopetition perspective of global competition. Journal of World Business, 42, 129-144. https://doi.org/10.1016/j.jwb.2006.08.007

Luo, Y. (2004). A Coopetition Perspective of MNC-host Government Relations. Journal of International Management, 10, 431-451. https://doi.org/10.1016/j.intman.2004.08.004

Mia, L., \& Clarke, B. (1999). Market competition, management accounting systems and business unit performance. Management Accounting Research, 10, 137-158. https://doi.org/10.1006/mare.1998.0097

Miotti, L., \& Sachwald, F. (2003). Co-operative R\&D: Why and with whom? An integrated framework of analysis. Research Policy, 32(8), 1481-1499. https://doi.org/10.1016/S0048-7333(02)00159-2

Nalebuff, B., \& Brandenburger, A. (1996). La Coopétition, une révolution dans la manière de jouer concurrence et coopération. Paris, Village Mondial.

Pecotich, A., Hattie, J., \& Low, L. P. (1999). Development of Industruct: A Scale for the Measurement of Perceptions of Industry Structure. Marketing Letters, 10(4), 409-422. Kluwer Academic Publishers, Manufactured in the Netherlands. Retrieved from https://www.jstor.org/stable/40216551

Pellegrin-Boucher, E., \& Le Roy, F. (2009). Dynamique des stratégies de coopétition dans le secteur des TIC: le cas des ERP. Revue Finance-Contrôle-Stratégie, 12(3), 97130. Retrieved from $\mathrm{http}: / /$ crego.u-bourgogne.fr/images/stories/rev/123130.pdf

Penrose, E. T. (1959). The Theory of the Growth of the Firm. Oxford University Press: Oxford. https://doi.org/10.1093/0198289774.001.0001

Porter, M. E. (1980). Competitive Strategy: Techniques for Analyzing Industries and Competitors. New York: Free Press.

Rumelt, R. (1984). Theory strategy and entrepreneurship. In R. Lamb (Ed.), Competitive strategic management. Prentice Hall. https://doi.org/10.1007/0-387-23622-8_2

Sanou, F. H. (2012). Les déterminants de la coopétition dans l'industrie de la téléphonie mobile. AIMS.

Sanou, F. H., \& Le Roy, F. (2012). Agressivité, Coopération Ou Coopétition: Quelle Stratégie Performante Dans Les Industries De Réseaux? Working Paper. Retrieved from https://hal.umontpellier.fr/hal-02048035

Seznich, Ph. (1957). Intuitionalism "Old" and "New". Administrative Science Quarterly, 41(2), 270-277. https://doi.org/10.2307/2393719

Shan, W. (1990). An empirical analysis of organizational strategies by entrepreneurial High-technology Firms. Strategic Management Journal, 11, 129-139. https://doi.org/10.1002/smj.4250110205

Smith, K. G., Grimm, C. M., \& Gannon, M. J. (1992). Dynamics of competitive strategy. Sage Publications.

Spanos, Y. E., \& Lioukas, S. (2001). An Examination into The Causal Logic of Rent Generation: Contrasting Porter's Competitive Strategy Framework and The Resource-Based Perspective. Strategic Management Journal, 22, 907-934. https://doi.org/10.1002/smj.174

Weerawardena, J., Aron, O., \& Julian, C. (2006). Does industry matter? Examining the role of industry structure and organizational learning in innovation and brand performance. Journal of Business Research, 59, 37-45. https://doi.org/10.1016/j.jbusres.2005.02.004

Wernerfelt, B. (1984). A Resource View of the Firm. Strategic Management Journal, 5(2), 171-180. https://doi.org/10.1002/smj.4250050207

Zineldin, M. (2004). Co-opetition: The organization of the future. Mark. Intell. Plan, 22, 780-789. https://doi.org/10.1108/02634500410568600 


\section{Appendix}

Table 3. Tests' Results of research hypotheses

\begin{tabular}{cccc}
\hline \multirow{2}{*}{ Variables' Relationship } & \multicolumn{2}{c}{ Estimated beta } & \multirow{2}{*}{ CR } \\
\cline { 2 - 3 } & NS & S & \\
\hline SCOPTH $<-$-IC &, 013 &, $013^{* * *}$ & $-2,194$ \\
SCOPTHC<--IC &,- 124 &,$- 157^{*}$ & 3,600 \\
CPTHAG--IC &, 181 &, $269^{* * *}$ & $-8,261$ \\
SCPTV--IC &,- 503 &,$- 503 * * *$ & $-7,765$ \\
SCPTVC $<-$-IC &,- 568 &,$- 531 * * *$ & $-6,565$ \\
CPTVAG--IC &,- 535 &,$- 550^{* * *}$ & $-10,856$ \\
SCOPTH<--CS &,- 607 &,$- 607 * * *$ & $-6,377$ \\
SCOPTHC<--CS &,- 531 &,$- 408^{* * *}$ & $-6,284$ \\
CPTHAG<--CS &,- 335 &,$- 626^{* * *}$ & $-11,172$ \\
SCPTV--CS &,- 618 &,$- 618^{* * *}$ & $-8,950$ \\
SCPTVC<--CS &,- 668 &,$- 584 * * *$ & $-10,718$ \\
CPTVAG $<-$-CS &,- 954 &,$- 768^{* * *}$ &
\end{tabular}

$* * *, * *, *$ : significative at $1 \%, 5 \%, 10 \%$

IC: Competitive Intensity, CS: Strategic Capabilities, SCOPTH: Horizontal Coopetition, SCPTV: Vertical Coopetition, SCOPTHC: propensity to cooperation in horizontal coopetition, CPTHAG: propensity to aggression in horizontal coopetition, SCOPTVC: propensity to cooperation in vertical coopetition, CPTVAG: propensity to aggression in vertical coopetition

\section{Copyrights}

Copyright for this article is retained by the author(s), with first publication rights granted to the journal.

This is an open-access article distributed under the terms and conditions of the Creative Commons Attribution license (http://creativecommons.org/licenses/by/4.0/). 